\title{
Kesehatan Reproduksi Ternak dan Inseminasi Buatan Pada Kelompok Peternak Sapi Potong Putra Nusa Pangandaran
}

\section{Animal Reproductive Health and Artificial Insemination (AI) Beef Cattle at Beef cattle Farmer Group Putra Nusa Pangandaran}

\author{
Siti Darodjah Rasad ${ }^{1, a}$, Rini Widyastuti ${ }^{1}$, Novi Mayasari ${ }^{2}$, Kikin Winangun ${ }^{1}$, Annisaa Yusrina ${ }^{1}$, Fahmy \\ Avicenna ${ }^{1}$ \\ ${ }^{1}$ Lab. Reproduksi Ternak, Fakultas Peternakan, Universitas Padjadjaran, Jatinangor, Kab. Sumedang \\ ${ }^{2}$ Lab. Fisiologi Ternak dan Biokimia, Fakultas Peternakan, Universitas Padjadjaran, Jatinangor, Kab. \\ Sumedang \\ aemail: s.d.rasad@unpad.ac.id
}

\begin{abstract}
Abstrak
Tujuan dari program pengabdian kepada masyarakat ini adalah untuk menambah wawasan peternak Sapi Potong tentang kesehatan reproduksi dan teknik Inseminasi Buatan (IB). Metode yang dilaksanakan diawali dengan penjajagan berupa pertemuan informal guna mempermudah dan memperlancar kegiatan penyuluhan Selanjutnya penyuluhan dilaksanakan pada lokasi yang telah ditentukan dengan peserta penyuluhan adalan anggota kelompok peternak Sapi Potong Putra Nusa Pangandaran. Pekasanaan penyuluhan meliputi pre-test, penyampaian materi, diskusi, serta posttest. Hasil dari pelaksanaan penyuluhan tersebut adalah kegiatan penyuluhan dapat meningkatkan wawasan peternak peserta penyuluhan. Dari pelaksanaan PKM tersebut dapat disimpulkan bahwa peternak mengerti tentang aspek kesehatan reproduksi pada ternak dan berhasil menjelaskan keuntungan dan kerugian pelaksanaan IB serta peternak mampu menjelaskan syarat pelaksanaan IB yang direkomendasikan dalam manajemen perbibitan sapi potong, serta terjadi peningkatan wawasan peternak mengenai teknik Inseminasi Buatan (Penampungan semen dan teknik IB).

Kata Kunci: Kesehatan reproduksi, IB, Sapi Pasundan, Pangandaran
\end{abstract}

\begin{abstract}
The purpose of this community service program is to improve the knowledge of the beef cattle breeders' about reproductive health and Artificial Insemination (AI) techniques. The method implemented begins with informal meetings to facilitate the extension activities. Furthermore, the extension is carried out at a location that has been determined with the participants is a beef cattle farmer group of Putra Nusa Pangandaran. Extension training includes pre-test, delivery of the material, discussion, and post-test. The results of the implementation is that extension activities can increase the knowledge of the farmers. From the implementation of the extension, it can be concluded that the farmers understands about the reproductive health in livestock and successfully to explains the advantages and disadvantages of AI techniques and the farmer is able to the recommended AI programs requirements in beef cattle breeding management, as well as an increase the farmers' insights regarding Artificial Insemination techniques.
\end{abstract}

Keywords: reproductive health, AI, Pasundan cattle, Pangandaran 


\section{Pendahuluan}

Peranan Sumber Daya Genetik Ternak (SDGT) sangat penting seiring dengan meningkatnya kebutuhan manusia terhadap pangan, kesehatan, ekonomi, sosial dan budaya di masa sekarang dan akan datang. Menurut Setiadi dan Diwyanto (1997) bahwa peningkatan kebutuhan pangan dan pemanfaatan SDGT telah mendorong petani dan pemulia ternak untuk menciptakan rumpun/galur/strain baru ternak dengan mutu yang lebih baik dan nilai nyata yang lebih tinggi. Sapi Pasundan merupakan sapi lokal Jawa Barat yang telah ditetapkan sebagai rumpun khas Jawa Barat berdasarkan SK Menteri Pertanian Nomor 1051/Kpts/RI/SR.120/10/2014 (Kementan RI, 2014).

Sebagai salah satu sumber protein hewani, daging sapi mempunyai nilai strategis dalam perekonomian Indonesia. Pertumbuhan produksi daging sapi nasional relatif lebih lambat dibandingkan dengan pertumbuhan konsumsi sehingga impor daging sapi cenderung meningkat dari waktu ke waktu. Rendahnya pertumbuhan produksi daging sapi nasional sebagai akibat dari rendahnya tingkat produktivitas ternak sapi potong (Kusriatmi, dkk., 2014).

Permasalahan yang terjadi diakibatkan sistem pemeliharaan sapi potong termasuk sapi Pasundan pada umumnya masih bersifat tradisional, diusahakan oleh peternak rakyat dengan jumlah kepemilikan relatif sedikit. Manajemen pemeliharaan masih sangat sederhana belum menerapkan inovasi teknologi baik dalam manajemen pakan maupun manajemen reproduksi. Sehingga berdampak terhadap rendahnya tingkat produktivitas dan pada gilirannya perkembangan populasi menjadi rendah.
Keterbatasan pengetahuan dan sumber daya yang dimiliki merupakan kendala dalam pengembangan usaha ternak sapi Pasundan.

Kondisi lingkungan, di daerah Pangandaran memiliki potensi yang baik untuk pengembangan sapi Pasundan, dilihat dari ketersediaan hijauan sebagai pakan ternak baik rumput ataupun hasil ikutan pertanian. Namun sampai sejauh ini usaha peternakan sapi Pasundan yang dilakukan peternak belum berkembang seperti yang diharapkan. Adanya pembinaan dan peningkatan pengetahuan peternak serta inovasi teknologi perlu dilakukan, diantaranya Inseminasi Buatan (IB) dan Recording atau pencatatan serta informasi tentang kesehatan reproduksi ternak (Usmani, dkk., 2001).

Salah satu langkah dalam kebijakan swasembada daging sapi adalah peningkatan produktivitas ternak sapi potong melalui optimalisasi Inseminasi Buatan untuk mendorong pertumbuhan produksi daging sapi nasional,terutama di wilayah-wilayah pesisir. Desa Kondangjaya Pangandaran merupakan wilayah kerja Kelompok Peternak Sapi Potong yang bertujuan untuk pembibitan sapi potong

Inseminasi Buatan (IB) adalah teknologi reproduksi dengan cara memasukkan semen ke dalam alat kelamin hewan betina sehat dengan menggunakan alat inseminasi agar hewan tersebut menjadi bunting (Dirjen Peternakan dan Kesehatan Hewan, 2012). Selanjutnya Ax, dkk (2008) menyatakan bahwa IB merupakan tehnik yang digunakan guna meningkatkan kemampuan genetik ternak.

Adanya IB mempermudah dalam manajemen kawin, peternak tidak harus memiliki pejantan, harga pejantan yang berkualitas relatif mahal, tidak semua peternak memiliki pejantan. Sperma yang 
digunakan dalam IB dapat dipilih atau diambil dari pejantan unggul, sehingga dapat menghasilkan keturunan yang lebih baik, dan diharapkan mampu meningkatkan produktivitas dan mempercepat perkembangan populasi (Mitchell dan Doak, 2004). Pada tahun 2007 sekitar 81,77 persen sapi betina yang melakukan perkawinan dengan teknik IB berhasil bunting dan 42,18 persen diantaranya berhasil bunting dengan sekali aplikasi IB. Tahun 2008 tingkat keberhasilannya meningkat menjadi 97,45 persen dan 55,84 persen diantaranya berhasil bunting dengan sekali aplikasi IB (BPS dan Dirjen Peternakan, 2007; 2009 dalam Kusriatmi, dkk., 2014). Adanya optimalisasi teknologi IB diharapkan akan memperpendek kelahiran, sehingga akan mendorong peningkatan produksi ternak sapi potong. Dalam blue print PSDSK 2014, dengan peningkatan aplikasi dosis IB maka calving interval (jarak beranak) diharapkan bisa diperpendek dari rata-rata 21 bulan menjadi 17,5 bulan atau 15 bulan (skenario optimistik) (Dirjen Peternakan, 2011) dan ini sesuai dengan pendapat Driancourt, (2001) dan Wiltban, dkk., (2002) bahwa calving interval ideal pada sapi potong adalah antara 15 - 17,5 bulan.

Selama ini penerapan IB dan recording di kalangan peternak rakyat pada umumnya belum dilakukan. Keterbatasan informasi dan atau kurangnya sosialisasi teknologi tepat guna di kalangan peternak menjadi salah satu faktor penyebab kurang memasyarakatnya teknologi tersebut. Sasaran utama target pembinaan adalah kelompok peternak Sapi Pasundan Putra Nusa Pangandaran. Kegiatan penyuluhan berupa transfer pengetahuan dan teknologi serta meningkatkan wawasan peternak sapi mengenai kesehatan reproduksi dan program IB sapi Pasundan. Melalui program penyuluhan ini, diharapkan peternak akan mampu mengelola usahanya dengan baik dan pada akhirnya mampu meningkatkan produktivitas ternaknya .

\section{Materi dan Metode}

\section{Metode yang digunakan}

Sebelum melaksanakan penyuluhan, dilaksanakan penjajagan berupa pertemuan informal guna mempermudah dan memperlancar kegiatan penyuluhan. Metode pelaksanaan kegiatan menggunakan pendekatan PRA (participatory rural appraisal) sehingga pendekatan formal dan informal diperlukan dalam pelaksanaan penyuluhan dengan upaya untuk mendapatkan respon yang positif dari masyarakat untuk hadir dalam kegiatan penyuluhan. Penyuluhan dilaksanakan di tempat yang disarankan oleh kelompok setempat serta pelaksanaannya meliputi pre-test, penyampaian materi, diskusi, serta posttest. Hasil evaluasi pre-test dan post-test digunakan untuk mengetahui pengaruh pemberian materi.

\section{Partisipasi masyarakat}

Partisipasi peternak dalam kegiatan ini adalah menyediakan ternak sapi Pasundan membantu proses transfer teknologi, dan berperan aktif dalam proses diskusi dan evaluasi hasil. Partisipasi masyarakat tersebut difasilitasi melalui kelompok ternak sapi potong Putra Nusa, sehingga dalam program pembinaan dan pendampingan dilakukan melalui kelompok.

\section{Tenaga Ahli}

Tim pelaksana kegiatan ini terdiri dari tiga orang dosen, dua orang asisten dosen 
dan satu orang teknisi dengan latar belakang kelimuan dan kualifikasi sesuai dengan dengan topik kegiatan. Bidang keahlian tim adalah 2 orang di Bidang Reproduksi Ternak dan 1 orang di Bidang Fisiologi Ternak. Bidang tersebut sangat sesuai dengan dalam proses transfer pengetahuan dan teknologi bagi peternak sapi. Dalam hal transfer pengetahuan kepada masyarakat, tim mempunyai pengalaman pengabdian kepada masyarakat di berbagai daerah.

\section{Materi Kegiatan}

Materi kegiatan meliputi :

a. Uraian tentang sistem reproduksi sapi potong termasuk deteksi berahi

b. Uraian mengenai keuntungan dan kerugian penerapan inseminasi buatan pada ternak sapi potong

c. Pelatihan pelaksanaan inseminasi buatan pada ternak sapi potong melalui tahapan:

- Cara penampungan semen dengan metode Vagina Buatan

- Cara penilaian semen (air mani) hasil penampungan.

- Cara pengenceran semen.

- Cara deposisi semen ke dalam saluran reproduksi ternak betina.

\section{Hasil dan Pembahasan}

\section{Kesehatan Reproduksi Sapi Potong}

Kelompok Peternak Putra Nusa (KPPN) adalah salah satu kelompok peternak yang berlokasi di Desa Kondangjaya, Kecamatan Cijulang, Kabupaten Pangandaran. Tujuan utama aktivitas di KPPN adalah pembibitan dan perkembangbiakan sapi potong. Kegiatan utama di KPPN adalah melakukan perencanaan dan pelaksanaan perkembangbiakan sapi potong, kemudian dilakukan pemeliharaan dari lahir hingga mencapai umur yang mencukupi untuk digemukkan oleh pelaku usaha penggemukan. Secara kronologis, KPPN mendapatkan bantuan modal awal berupa bibit sapi potong sebanyak 70 ekor dari Pemerintah Provinsi Jawa Barat, lalu dilakukan pembagian bibit sapi potong kepada seluruh anggotanya. Jumlah anggota KPPN adalah sebanyak 35 orang, sehingga setiap orang dialokasikan memiliki 2 ekor sapi.

Hasil yang diperoleh mengenai wawasan manajemen kesehatan reproduksi para peternak sapi potong dapat dilihat pada Tabel 1.

Tabel 1. Manajemen Reproduksi

\begin{tabular}{clrrrr}
\hline \multirow{2}{*}{ No Pertanyaan } & \multicolumn{2}{c}{ Pre-Test } & \multicolumn{2}{c}{ Post-Test } \\
\cline { 3 - 6 } & & \multicolumn{2}{c}{ Ya } & Tidak & \multicolumn{1}{c}{ Ya } \\
\hline 1 & Tata cara seleksi bibit dan indukan sapi potong & 10 & 0 & 10 & 0 \\
2 & Deteksi beger dan manajemen perkawinan Pertama & 9 & 1 & 10 & 0 \\
3 & Perawatan induk sapi pada saat kebuntingan & 10 & 0 & 10 & 0 \\
4 & Induk sapi pada saat kelahiran & 10 & 0 & 10 & 0 \\
5 & Perawatan Induk pada saat laktasi/menyusui & 10 & 0 & 10 & 0 \\
6 & Penanganan induk saat beger setelah melahirkan & 9 & 1 & 10 & 0 \\
7 & Penanganan anak baru lahir & 10 & 0 & 10 & 0 \\
8 & Penanganan anak lepas sapih & 10 & 0 & 9 & 1 \\
9 & Perbedaan pemberian pakan pada dara, induk, dan anak & 2 & 8 & 2 & 8 \\
10 & Aplikasi teknologi reproduksi, sinkronisasi berahi, dan & 10 & 0 & 10 & 0 \\
\hline
\end{tabular}


Berdasarkan tabel diatas, segera setelah dilakukan penyuluhan mayoritas peternak memahami berbagai masalah mengenai manajemen kesehatan reproduksi ternak sapi potong. Hal ini tercermin dari hasil pelaksanaan pre-test dan post-test. Namun, dalam pemberian pakan, para peternak tidak melakukan pembedaan antar usia ternak (dara, induk, dan anak). Hal ini disebabkan oleh ketersediaan pakan yang sangat terbatas sehingga tidak memungkinkan para peternak untuk memberikan pakan yang berbeda pada masing-masing fase/usia ternak yang dipelihara.

\section{Teknik Inseminasi Buatan Sapi Potong}

Hasil pelaksanaan penyuluhan mengenai teknik inseminasi buatan pada sapi potong dapat dilihat pada Tabel 2 berikut.

Tabel 2. Teknik Inseminasi Buatan Sapi Potong

\begin{tabular}{ccccc}
\hline \multirow{2}{*}{ Peternak } & \multicolumn{2}{c}{ Pre-Test } & \multicolumn{2}{c}{ Post-Test } \\
\cline { 2 - 5 } & Ya & Tidak & Ya & Tidak \\
\hline 1 & 5 & 5 & 9 & 1 \\
2 & 4 & 6 & 8 & 2 \\
3 & 6 & 4 & 7 & 3 \\
4 & 8 & 2 & 9 & 1 \\
5 & 9 & 1 & 10 & 0 \\
6 & 8 & 2 & 9 & 1 \\
7 & 9 & 1 & 10 & 0 \\
\hline
\end{tabular}

Tabel 2 menggambarkan rekapitulasi tanggapan peternak terhadap kuesioner tentang Teknik Inseminasi Buatan (IB). Pada kegiatan penyuluhan tersebut, selain menjelaskan secara teori teknik IB, telah dilakukan pula demonstrasi cara penampungan semen dan teknik IB. Dari kegiatan tersebut terlihat adanya perubahan wawasan dan pengetahuan peternak saat pre test dan post test. Dari Tabel 2 tersebut terlihat adanya peningkatan pengetahuan peternak, walaupun yang mengikuti pelatihan hanya 7 orang peternak, tetapi dapat menggambarkan bagaimana peternak tersebut mengikuti penyuluhan tersebut.

\section{Kesimpulan}

Dari kegiatan penyuluhan selama melaksanakan program PKM, dapat disimpulkan bahwa kegiatan penyuluhan mengenai kesehatan reproduksi dan aplikasi teknologi inseminasi buatan sapi potong berhasil dilaksanakan. Wawasan peternak meningkat dalam aspek manajemen kesehatan reproduksi ternak sapi potong. Antusiasme peternak peserta penyuluhan dalam kegiatan penyuluhan sangat tinggi tercermin dari keberhasilan peternak untuk menjelaskan keuntungan dan kerugian pelaksanaan IB serta peternak mampu menjelaskan syarat pelaksanaan IB yang direkomendasikan dalam manajemen perbibitan sapi potong, serta terjadi peningkatan wawasan peternak mengenai teknik Inseminasi Buatan (Penampungan semen dan teknik IB). 


\section{Daftar Pustaka}

Ax, R. L., Dally, M.R., Didion, B.A., Lenz, R.W., Love, CC., Varner, DD., Hafez, B., dan Bellin, ME., 2008. Artificial Insemination. In: Hafez, ESE and Hafez, B., ed. Reproduction in Farm Animals. $7^{\text {th }}$ ed. Blackwell Publishing. 376.

Dirjen Peternakan dan Kesehatan Hewan. 2012. Pedoman Optimalisasi Inseminasi Buatan (IB) Tahun 2012. Direktorat Jenderal Peternakan dan Kesehatan Hewan, Kementrian Pertanian. Jakarta

Dirjen Peternakan. 2011. Blue Print Program Swasembada Daging Sapi 2014. Direktorat Jenderal Peternakan, Kementerian Pertanian Jakarta [internet]. [dapat diunduh di http://www.ditjennak.go. $\mathrm{id} /$ regulasi\%5Cblueprint.pdf.

Driancourt., M.A. 2001. Regulation of ovarian follicular dynamics in farm animals. Implications for manipulation of reproduction. Theriogenology 55:1211-1239.

Kementerian Pertanian Republik Indonesia .2014. Surat Keputusan Menteri Pertanian Nomor 1051/Kpts/SR.120/10/2014 tentang penetapan rumpun sapi pasundan sebagai SDGT Jawa Barat

Kusriatmi, F.N., Rina, O., Yusman, S., Ali, S. 2014. Peranan Teknologi Inseminasi Buatan (IB) pada Produksi Sapi Potong di Indonesia. J. Agro Ekonomi 32(1).57-74.

Mitchell J.R. and G.A. Doak. 2004. The Artificial Insemination and Embryo Transfer of Dairy and Beef Cattle. Pearson Prentice Hall. 3-6

Setiadi, B. dan Diwyanto K. 1997. Karakterisasi morfologis sapi
Madura. Jurnal Ilmu Ternak dan Veteriner 2(4): 218-224.

Usmani, R.H., A.N. Ahmad, Shafiq, P. and Mirza, M.A. 2001. Effect of subclinical uterine infection on vervical and uterine involution, estrous activity and fertility in postpartum buffaloes. Theriogenology 55:563-571.

Wiltban, M.C., Gtimen, A., and Sartori, R. 2002. Physiological classification anovulatory conditions in cattle. Theriogenology 57:21-52. 